\title{
Agenda Setting and Intra-Party Deliberation: Who gets represented at party national meetings? ${ }^{1}$
}

\author{
Zachary Greene, University of Strathclyde \\ zacgreene@gmail.com \\ Javier Sajuria, Queen Mary University of London \\ j.sajuria@qmul.ac.uk
}

\section{Brief Overview}

We predict that party leaders screen the content of speeches delivered at party national meetings, but allow dissent in some contexts. We analyse data on candidate surveys and speeches to evaluate propositions from our theory.

\begin{abstract}
National party meetings provide members with opportunities to express distinct preferences and issue priorities that guide the party's future policies. Although scholars recognize that party leaders dominate the structure and content of meetings, little empirical research examines the extent of their agenda setting role. Who gets to speak and whose preferences get represented? Adapting theories of legislative agenda setting to the intra-party context, we hypothesize that party candidates are less likely to be chosen as speakers at party conferences when the party's leadership most demands unity due to their incumbency status. Using self-placements from candidate surveys, we predict the likelihood that MPs and leaders speak at parties' national meetings in the U.K. We then link candidates' selfplacements to the content of speeches using automated text analysis. These results add to a broad theory of party decision-making which perceives parties' national meetings as a forum for information sharing, intra-party competition and deliberation. More broadly, evidence in line with this approach suggests that treating parties as unitary actors in a range of settings overlooks important intra-party divisions.
\end{abstract}

Key Words: Intra-party politics, agenda-setting, MP surveys, party congresses, text analysis

\footnotetext{
${ }^{1}$ This is a draft version, please do not cite without permission. For all queries, contact us at zacgreene@gmail.com.
} 
Studies of intra-party politics make strong claims about the role of party activists, members, and leaders. Intra-party factions vie for the leadership, influence the policy direction and even constrain the party's behavior in government (e.g. Ceron 2015). Yet, the process through which intra-party groups have this effect is often under-developed in theories of intra-party decision-making. From this perspective, national party meetings allow a diverse party membership to deliberate on and select their leaders and the party's future direction, while party leaders simultaneously use meetings to convey information to members and external observers about their priorities. Less is known about the structure and content of these meetings. Studies have largely remained silent on intra-party decisionmaking mechanisms, although many indicate that national meetings and party conferences likely play a prominent role. Given the centrality of these meetings to the selection and maintenance of the party's leadership and policy strategies, intra-party groups should seek to use them to benefit their own priorities.

Building on this perspective, we propose a theory of intra-party politics and decision-making that places party leaders in a paramount position. Much like theories of legislative agenda-setting, we contend that party national meetings act as a form of intraparty parliament. Like their parliamentary equivalents, the leadership likely uses restrictive procedures to limit the diversity of preferences expressed at these meetings to support their intra-party policy goals (e.g. Döring 2003). However, leaders are faced with competing demands to incorporate diverse goals from intra-party factions to maintain the party's national electoral coalition while also structuring the content of debates to support their own policies. This perspective predicts that party leaders will allow greater expression of preferences when they need the support of diverse factions the most, in the opposition.

As a test case, we evaluate hypotheses from our Theory of Intra-Party DecisionMaking by combining data from parties in the United Kingdom using two previously disconnected sources on the preferences of party members: MP candidate surveys and 
speeches from party national meetings. ${ }^{2}$ By treating electoral candidates as the potential pool of speakers at party conferences, we predict the likelihood that they participate in these meetings from their perceived ideological similarity with the party's position. Furthermore, the goals expressed in their speeches will be consistent with their responses to candidate surveys, yet demonstrate a more limited ideological range if the party applies a screening mechanism. We find compelling preliminary evidence for intra-party agenda setting in the United Kingdom.

This research holds serious consequences for the study of intra-party politics and decision-making. Party leaders likely limit the intra-party agenda to demand a show of party unity, but incorporate broad perceptions to build electoral coalitions. Intra-party debates, therefore, are likely to be most salient when the party has little left to lose. This evidence further suggests that the both candidate surveys and speeches at party national meetings reflect the latent preferences of intra-party groups. Finally, evidence of intra-party agenda setting likely implies that party electoral and communication strategies can only be as successful as leaders' control of the party's rules. A lack of control might allow the appearance of a disunited party ridden with infighting and factions or an unclear policy message, but an overly constrained party might create the context in which party members become dispirited and unmotivated. Public evidence of major party divisions such as the British Labour Party under Jeremy Corbyn or the Democratic Party's support of Hilary Clinton in the last US elections highlight when the balance between central party control goes wrong. These considerations imply that parties play a far reaching and complex role in aggregating diverse sets of preferences and constituencies.

\footnotetext{
${ }^{2}$ We refer to party national meetings, party congresses and party conferences interchangeably throughout the manuscript. Our theory and empirical analysis considers the largest national meetings that parties host to discuss and make decisions on the party's policy, electoral and strategic goals.
} 
As teams of people with the intention of controlling government and changing policy (Downs 1957), party activists, members, representatives and leaders share the common goal of governing together. Yet, there are abundant examples of intra-party disagreements over the details of policies. In the face of complex political environments, differences arise between members for a multitude of reasons: leaders and members hold uncertainty over the success of their electoral strategies (Adams et al. 2014); regional variation in geography, governance and even public opinion introduce distinct regional policy challenges (e.g. Bäck et al. 2016); and groups within parties likely differ in their exact policy goals or policy-making strategies (e.g. Kitschelt 1989; van Haute and Carty 2012; Kölln and Polk 2017). Taken to an extreme, party divisions even lead to MPs switch parties and party splits as members' policy differences become so great as to overcome the common governing priority (O’Brien and Shomer 2013; Ibenskas and Sikk 2017).

Divided parties demand tools that aggregate and negotiate tricky differences between members so they can collectively control government (Aldrich 2015). In contexts with single-member district electoral systems such as the United Kingdom, candidates often face incentives to distinguish their positions from the party's line to maximize their chance of attracting the plurality of votes in ideologically distinct districts (e.g. Downs 1957; Carey and Shugart 1995; Huber 1996). Yet, the perception of party division limits the party's chance of winning votes across districts as voters view them as incapable of implementing their policy goals in parliament and consequently as less competent organizations (Greene and Haber 2015). Furthermore, procedural rules in the British House of Comments limit the likelihood that MPs will distinguish their activities in Parliament through their voting behaviors (Cox 2005), although question time and open debate allow MPs to express distinct policy priorities (Döring 2003). 
Substantial work explains the ways in which parties overcome collective action problems. The logic follows that submission to the party leader's exact policy goals increase the likelihood of drawing policy towards a MP's policy. Theoretically, a MP could benefit their potential future electoral success by rebelling from the leadership on issues that the party deviates from their constituents' views. As the recent examples such as the repeal of Obamacare in the United States or the open vote for intervening in Syria in the UK in 2014, however, parties incapable of maintaining discipline in parliament will be incapable of substantially modifying policy. Divided parties limit their own policy-making abilities by increasing the amount of (limited) time necessary for parliaments to deliberate over their policy goals (Haber 2015). Presumably, parties and MPs seek to establish rules that encourage party members to cooperate towards common policy goals. This work often focuses on the role of electoral rules and the effect of decision-making rules in parliaments (Cox and McCubbins 1993, 2005; Bowler et al. 1999; Cox 2005).

Increasing work studies the politics within parties. Although there is an increasingly large amount of information on the role of the rules that constrain parties and changes in party membership (e.g. Harmel and Tan 1997; Kölln 2015, 2016; van Haute and Gauja 2015; Poguntke et al. 2016), less work directly empirically examines the preferences and behaviors of intra-party groups (Kölln and Polk 2017). Scholars have built on this work to consider the effect of party rules influence parties' behavior and perceptions of parties outside of the parliamentary arena. This work considers party membership and changes in parties' leadership election rules on the leaders' influence (Harmel et al. 1995; Kenig 2009a, 2009b) and voters' perceptions of the parties (Greene and Haber 2015; Shomer et al. 2016). Candidate selection procedures and electoral rules encourage MPs to exhibit personal voteseeking behavior (e.g. Carey and Shugart 1995; Shomer 2014, 2016).

Studies of party decision-making emphasize the ways party leaders manage intraparty groups. Theories of intra-party politics often made strong assumptions about the 
relative goals of parties and leaders (e.g. Kitschelt 1989; Harmel and Janda 1994; Schofield and Sened 2006). From this perspective, party leaders balance their policy statements in such a way to attract voters while also mobilizing activists (e.g. Schofield and Sened 2006). Parties' positions shift away from more extreme activist positions when voters hold more positive perceptions of the party leaders.

Empirically, party factions and intra-party groups seem to hold sway over the party's direction through their participation in party conferences, leadership selection and the manifesto writing process even if party leaders engage in substantial gate keeping activities (e.g. Gauja 2013). For example, intra-party votes on the party's leadership tend to reward candidates closer to the ideological center of the party (e.g. Greene and Haber 2016). Parties' policy changes shift in line more with their constituents' preferences than with the broader electorate (Green 2007; Ezrow et al. 2011; Spoon 2011). Divided parties ultimately respond to issues such as Euroskepticism more that more unified parties (Spoon and Williams 2017). Likewise, intra-party factions constrain the parties' positions, particularly closer to election time (e.g. Ceron 2014). Cross-national evidence highlights that the diversity of MPs matters as those parties with more female MPs take positions farther to the ideological left due to the inclusion of issues associated with more historically left positions (O'Brien 2015; Greene and O'Brien 2016). Intra-party factions even influence leaders' ability to enter governing coalitions (Debus and Brauninger 2009; Greene and Jensen 2014). Party rules and intra-party division correlate with differences in party policy changes (Schumacher et al. 2013; Haber 2015). Furthermore, party level rules seemingly change more frequently than government institutions and are more easily under the control of intra-party groups (e.g. Kenig 2009a, 2009b; Shomer et al. 2015).

Altogether, this research suggests that parties' decision-making processes hold important consequences for politics. Party national meetings provide the context in which 
many of these important decisions are made. Yet, few studies have directly outlined the characteristics of those that participate in parties' meetings. Do factions or the current party leaders decide who participates and can vote in these meetings? The answer to this question will shed light not only on the ways in which parties function as organizations, but also reveal the extent to which parties act as if they are unitary actors in strategic settings.

Intra-party Agenda Setting

Like parliaments, party national meetings function as formal deliberative settings that likely serve multiple purposes. As decision-making venues, party leaders and members engage in policy debates and ultimately hold formal votes on the party's future direction. Like parties in many European countries, British political parties hold national meetings annually or biannually to bring together activists and representatives from local and regional organizations with the parties' national leadership. Although not all meetings involve votes on important decisions, these meetings provide members with the opportunity to engage in debates over the parties' future. For example, the 2017 Labour Party conference website welcomed visitors with the statement that "Our delegates and visitors take part in debates to shape Labour's vision for Britain."3 The Liberal Democrats offered a similar message stating that the "Autumn Conference ... features lively debates, speeches, policy discussions,...." 4 Intriguingly, the Conservative Party conference webpage placed less emphasis on participation instead stating that "...the Conference is a chance for our members, the press and the public to learn about our ideas and policies for the year

\footnotetext{
${ }^{3}$ http://www.labour.org.uk/pages/annual-conference-2017 (Accessed March 27, 2017).

${ }^{4}$ http://www.libdems.org.uk/autumn-conference (Accessed March 27, 2017).
} 
ahead." 5 Clearly, parties allow for encourage policy debates, but to what extent do the organizers shape the intra-party message or choice of messengers.

We conceptualize party national meetings as akin to other deliberative bodies such as national legislatures. From this perspective, attendees, like MPs to national parliaments, act as representatives for local, regional, internally organized interests or external organizations. Speakers deliberate over policies both to inform the attendees of the party's activities as well as build support for their specific policy goals. Similar to tools for controlling the legislative agenda (e.g. Döring 2001, 2003), party leaders control the terms of debate by influencing those allowed to speak and the order on the central body votes on motions. Historically, many parties even list the party conference formally as the ultimate decision-making authority within the party (e.g. Katz and Mair 1994).

This discussion implies that electorally motivated party leaders must contend with intra-party groups to construct policies, manifestos and even select and protect their positions in the party's leadership. From this perspective, the party leader, acting as the director of the intra-party agenda, holds influence within the party because of this agenda control. Leaders select the topics for debate, submit motions to vote on, and likely even limit the selection of speakers at these meetings. Intra-party agenda control allows leaders to selectively construct the party's policy message, while simultaneously motivating supportive activist groups to mobilize for elections. This explains the increased importance of intra-party factions as elections near (Ceron 2014).

We argue that intra-party agenda control incentivizes leaders to screen participants at party national conferences (for a similar perspective on intra-party gatekeeping, see Gauja 2013). Assuming that controlling government motivates party leaders, they will use their positions to benefit their national electoral success by avoiding the appearance of internal

\footnotetext{
${ }^{5}$ https://conservativepartyconference.com/index (Accessed March 27, 2017).
} 
conflict. Voters perceive parties failing to cultivate an image of cohesion as incapable of developing policy and consequently these parties likely face negative electoral consequences (e.g. Greene and Haber 2015). Given the incentives MPs face to cultivate personal votes in single member district systems such as the UK, party leaders must carefully limit the speakers at their national meetings if they are to create a unified party image, particularly as parliamentary rules incentivizing party cohesion are weakened. ${ }^{6}$ We assume that party leaders likely use broad information to assess the ideological proximity of potential speakers such as candidates' past speeches and experiences in the party and parliament, the constituencies they represent and even their part loyalty to the party leader. This implies that party leaders will limit the participation of MPs or candidates with ideologically distant preferences. Following this logic, we predict in the first hypothesis that more/less ideologically central (to the party core) MPs will be more/less likely to speak at parties' national meetings.

H1: Greater perceived distance with the party reduces the likelihood that the person speaks at the party conference.

The logic of the first hypothesis suggests a strong leader with complete control of the speaking agenda and one that has limited need of intra-party groups to remain in power. Yet, scholars have often assumed that party leaders depend on intra-party groups in different contexts, particularly to run and organize elections. Anecdotes from party meetings in numerous countries suggest that party national conferences contain more conflict than this account would suggest (see, for example, the discussion in Greene and Haber 2016). In some institutional contexts, these disagreements can even spill over into the creation of new

\footnotetext{
${ }^{6}$ Following the enactment of the 2011 Fixed Term Parliament Act, MPs' support is less necessary for a government to remain the government as a $2 / 3$ majority would be required to force new elections (e.g. ).
} 
parties or MPs even switching to other parties (e.g. O'Brien and Shomer 2013; Ibenskas and Sikk 2017).

Indeed, accounts of intra-party politics and electoral competition indicate contexts in which party leaders depend more on intra-party groups. Schofield and Sened (2006), for example, suggest that party activists become more important when the leadership benefits from less positive valence and resources such as when they are in the opposition. Participation in government even likely alters the types of activists that joint parties, encouraging more pragmatic activists seeking more incremental policy changes (Kitschelt 1989). Evidence from France and Germany suggests that participation in government leads to less evidence of intra-party disagreement at party congresses, particularly under positive economic conditions (Greene and Haber 2016). This is likely the exact context in which party leaders rely the least on intra-party groups for their future electoral success.

We argue that governing party leaders likely require less on intra-party support than their opposition counterparts. Government leaders use the resources of the state to implement their stated policy goals to make activists happy and have a recent policy reputation that voters link to the party (Green and Jennings 2012). Opposition parties require a more robust intra-party effort to run election campaigns. With little recent policy reputation, access to government resources, or even well-known leaders, party leaders must mobilize intra-party groups to build an inclusive coalition of supporters. Mainstream parties in the opposition can ill afford to estrange groups within the party.

Ultimately, the difference between parties in government and the opposition suggest competing dynamics for intra-party agenda control, particularly when the government benefits from positive economic context (e.g. Green and Jennings 2012). Whereas the governing incumbent has substantial resources and already controls government, opposition party leaders are incentivized to build a diverse and inclusive intra-party coalition. Incumbents value pragmatic and unified policy messages to appear competent, 
whereas opposition leaders cultivating diverse support benefit from encouraging broad policy debates with little fear of contradicting the government's position (e.g. Greene 2016). This logic suggests that the effect of ideological distance within the party is conditional on the party's position in government or the opposition. Opposition parties will allow for greater ideological divergence than incumbents. Our second hypothesis summarizes the empirical prediction from perspective.

H2: Greater perceived distance within incumbent parties reduces the likelihood that a person speaks at the party conference, but increases the likelihood for speakers in opposition parties.

Building on this perspective, this discussion implies differences in the content of the speeches given at these meetings. Not only will those allowed to speak at incumbent party conferences hold more ideologically constrained positions than the diverse array encouraged at opposition party meetings, the speeches themselves will likely evidence these characteristics. As speakers bid for government benefits and fear negative reprisals from the party leadership in government, speakers at incumbent party congresses will be more constrained than the positions they express in the opposition. Ultimately, we predict that speeches at opposition party meetings will allow for a wider range of positions than those at incumbent party meetings. This logic leads to our final hypothesis on the range of positions expressed at party congresses.

H3: Speakers' expressed positions will exhibit less distance from the party's position than their perceived differences for incumbent parties. 
In summary, borrowing the logic of legislative agenda setting, we predict that party leaders screen the speakers at party meetings. Based on this perspective, we predict that more ideologically extreme party members will be less likely to speak at party national meetings than members more central to the party. Furthermore, incumbent leaders will exhibit stronger agenda control than party leaders in the opposition. Ultimately, incumbent intra-party agenda setting results in a more constrained range of positions expressed at the meetings than their opposition counterparts.

\section{Data and Methods}

To test hypotheses from the theory, we combine evidence from two previously disconnected sources on intra-party politics for mainstream parties in the United Kingdom. In particular, we combine responses from candidate surveys (CCS) with the speeches given at parties' national conferences for the Conservative party, the Labour Party, and the Liberal Democratic Party in 2009/ 2010 and 2014/2015. Recent evidence from these parties offer a challenging preliminary test of the theory as British parties have historically exhibited high levels of cohesion in parliament (e.g. Döring 2003; Cox 2005), but have experienced increased backbench rebellions and even parliamentary defeats on important bills (Bevan and John 2016; Willumsen and Goetz 2017).

To test our first set of hypotheses, we construct a dependent variable equal to one if the candidates in the CCS spoke at a party congress in the year of the election or the year after it. Presumably, those surveyed by the CCS act as a reasonable sample of potential speakers at these meetings. In practice, the large majority of candidates did not speak at any meeting, which is unsurprising given the limited number of potential speakers at these events. To reduce the sparseness of the dataset, we focus the analysis only on candidates that were already MPs prior to the election. This does not lead us to remove any 
respondents from the CCS that actually spoke at the parties' meetings.

We then combine these data with responses from candidate surveys to predict the likelihood of speaking at each meeting. In particular, we use the candidates' perceived distance from the party's position as our main predictor variable. We construct this variable by subtracting each candidate's self-placement on a left-right dimension the mean party placement by party members. We then take the absolute value as the measure of ideological distance. The average score of each party is taken by finding the mean score that all candidates assign to each party on a $0-10$, left to right scale. Candidate positions come from a question in which they are asked to place themselves on the same scale.

We also constructed a binary variable to denote whether the candidate belonged to the party in government or the party in opposition. This variable allows us to test for the conditional effect of agenda control. We also include a number of control variables such as the whether the candidate was an incumbent or not in the last election, their sex, race, and age.

In terms of descriptive statistics, the percentage of candidates in our sample that spoke in the conferences is $9 \%$ for 2010 and $8 \%$ for 2015 . The main independent variable, ideological distance, has the same average score in both waves, 1.22 points. The distribution between parties mostly changes from one election to the next one. For Conservatives, the average distance in 2010 was 0.99 and 1.21 in 2015. For Labour MPs, the distance decreased from 1.4 to 1.2, while for Liberal Democrats we see no change (1.22 points).

For each of the surveys of the year, we estimated logistic models with the variables mentioned above. To test H1, we focus on the coefficient for the variable measuring ideological distance. We test $\mathrm{H} 2$ by estimating a different model interacting the ideological distance with the binary variable stating if the candidate belongs to a party in government or opposition for each survey wave. Finally, we ran the same specifications with a pooled model, using both waves. 
To examine our final hypothesis, we require a measure of the content of the speeches at party conferences. Following recent approaches using automated content analysis (e.g. Slapin and Proksch 2008; Ceron 2012, 2014, 2015; Greene and Haber 2016), we scale each of the speeches given at the parties' meetings using the WORDFISH algorithm.7 We perform this analysis in separate models for each election year (2010 and 2015), including all speeches from all parties. We then take the individual speaker position estimates and compare those with the party's mean position in those years to find their ideological distance. For any speaker that we also have CCS estimates we perform OLS regression predicting the individual's self-placement from their expressed positions. ${ }^{8}$

Analysis I - Who speaks at party congresses?

We theorize that party leaders exhibit agenda control over the speakers at party congress meetings. This leads us to hypothesize that partisans perceiving themselves as more ideologically distant from the party's position will be less likely to speak at party national meetings (H1). We add that this effect will be stronger for governing parties, as opposition leaders might actually bring in more diverse speakers to build a larger intraparty coalition for electoral purposes (H2).

We present the main results of our logistic regression analyses in Table 1 . We first present the results for 2010 in Models 1 and 2 followed by the results for the 2015 meetings in Models 3 and 4 and the pooled analysis in Models 5 and 6. Contrary to our expectations in $\mathrm{H} 1$ and $\mathrm{H} 2$, the results from 2010 do not show a significant association between ideological distance and the probability of being a speaker in the party conference. This

\footnotetext{
${ }^{7}$ We follow standard pre-processing techniques to estimate each speaker's position (Proksch and Slapin 2009). In particular, we remove stop words, numbers, and punctuation. In the main analysis we use word stems.

${ }^{8}$ In future versions of this manuscript, we will include all years and speeches from the main analysis. We will also provide substantially more detail on how we performed and validated the analysis.
} 
result, however, changes for 2015. As it can be observed from Model 4, we observe a significant effect for the interaction between ideological distance. For MPs in opposition in 2015, more distance was associated with a higher probability of being selected as a speaker. This evidence confirms, partially, hypothesis 2 . After looking the pooled models, we cannot confirm $\mathrm{H} 1$ based on the survey data.

[Table 1 about here]

We graphically present the effect of perceived ideological distance on the likelihood of speaking at party national meetings in Figure 1. In particular, we transform the differential effects in Model 4 to predicted probabilities as a way to observe the substantive effect of the ideological distance. Figure 1 shows the change in predicted probabilities from the minimum to the maximum variation in the variable, while keeping all the other variables at their means or modal categories. Consistent with the second hypothesis, distance for opposition MPs leads to an increase in the probabilities of up to 0.35 (or 35\%) there is no obvious difference for speakers at the incumbent party. This story is consistent with a story in which opposition party leaders allow greater variation in preferences as they require support from a diverse intra-party coalition.

[Figure 1 about here]

Analysis II-Do incumbent parties screen the content of speeches at party congresses?

In our final hypothesis, we predict that the content of speeches at party national meetings will differ for opposition and incumbent parties. Speakers at these meetings will not only be hand selected for their ideological positions, but also will focus their speeches on content closer to the party's position than their surveyed positions would suggest (H3). 
Opposition parties should exhibit similar differences between their perceived positions and their positions derived from their speeches.

[Figure $2 \& 3$ about here]

To perform this analysis, we first estimated WORDFISH models for all speeches in 2010 and 2015 in two separate models. Because WORDFISH is a completely unsupervised method for deriving latent positions from text (the dimension of conflict is unknown in advance), the analysis requires that we examine the words that the model pulls out as distinguishing between the positions on the latent dimension. We present Tower Plots in Figure 2 and Figure 3 that reveal the relative location of each word (beta) and a weighting parameter (psi) that determines its influence on the estimates for each speaker position. Speakers that more frequently use words which are placed to a more negative position in a text are then assigned a more negative score. Words with a more negative weight (psi) have greater influence on the estimated speaker positions.

In 2010, as illustrated in Figure 2, a number of word stems having to do with child care and education place parties on the left such as "nurseri[es]", "gcse", "school", and "fellow" with a fairly impactful word weight. On the positive side, words related to an international conflict dimension such as "defenc[e]", "troop", "turkey", and "petrol" place speakers as more conservative (positive positions). This suggests that the largest difference between speakers in these conferences is over their position on international relations versus domestic politics issues.

Although words such as "gcse" and "studies" (along with "fee" and "test") still place speakers to the left, the negative end of the dimension takes on a decidedly more professions based appeal in 2015. Words such as "steel", "tech", "entrepreneur" now have a much stronger impact on speakers' placements. Terms now related to the conservative led teaching excellence framework such as "colleg[e]", "subject" and "school" stand out as well as references to the EU referendum which happened a year later in terms of "europ[e]", 
"refuge[e]", and "Brussel". The primary dimension of conflict seems to have become decidedly more anti-EU on the conservative end and more focused on employment issues for more leftward positions.

Using these scores, we then find the mean position for each party in those years and find the absolute difference between the party mean position and each speaker's position. This becomes the dependent variable in our final analysis. We demonstrate predicted positions from these two in Figure 4. As can be seen the positions largely align with expectations and there is some variation within each party group. A more refined analysis may be able to better separate the parties in the future.

Finally, we undertake a simple regression analysis with the cases matched from each party using the WORDFISH distance estimates as the dependent variable. The results largely match our expectations, although the extremely small sample size limits the variables from reaching standard levels of significance. Broadly consistent with the logic of our argument, it appears that the negative coefficient for the constitutive term for the distance measure based on the CCS indicates that speakers generally speak more in line with the party's position than their survey positions would predict. Furthermore, the interaction with the being in government is negative in every model. Intriguingly, a Wald test of the coefficients indicates that the combined effect is jointly significant in the 2010 and the pooled model and that the joint effect is significantly different from the constative term for perceived distance. This finding suggests that government parties limit the range of preferences speakers express more than those in the opposition.

\section{Discussion}

In this paper, we show evidence consistent with the perspective that party leaders have tools to manage intra-party conflicts. Through intra-party agenda control, leaders in 
incumbent parties, limit intra-party disagreements by selecting speakers close to the leadership. In contexts where party leaders require greater intra-party support (in the opposition), they mobilize groups by allowing greater ideological diversity in these meetings. Evidence from candidate surveys and the content of party congress speeches suggest that government parties are more likely to restrict policy discussions at their national meetings in the United Kingdom.

Despite the consistent (albeit weak) results, this analysis still faces a number of limitations as the number of observations, parties and years in government limit our ability to make general observations about party conferences in a wider range of countries. In future analyses we will integrate data from a larger range of countries and time periods.

However, the answer to the question of intra-party agenda control holds serious implications for the role of intra-party politics in advanced industrial democracies. Our preliminary results indicate that parties are most likely to act as if they are unitary actors when they control government. Party leaders limit alternative opinions when they can rely more on the resources of office and less on intra-party groups. We might expect then that parties exhibiting behavior that deviates from theories based on the unitary action would most likely be those in the opposition.

Ultimately, these results may help to explain evidence of a cost of governing and link to broader studies of election strategy and policy accountability. Government leaders are less likely to cultivate and maintain the intra-party coalitions that brought them to power if they exhibit overly strong intra-party agenda control. This approach implies that, ironically, the pathway for members and activists to influence the party's policy may emerge most when the party has the least actual policy influence, in the opposition. 


\section{Bibliography}

Adams, James, Lawrence Ezrow, and Zeynep Somer-Topcu. 2014. "Do Voters Respond to Party Manifestos or to a Wider Information Environment? An Analysis of Mass-Elite Linkages on European Integration." American Journal of Political Science 58(4): 967-978.

Bäck, Hanna, Marc Debus, and Heike Klüver. 2016. "Bicameralism, intra-party bargaining, and the formation of party policy positions: Evidence from the German federal system." Party politics 22(3): 405-417.

Bevan, Shaun, and Peter John. 2016. "Policy representation by party leaders and followers: what drives UK Prime Minister's Questions?" Government and opposition 51(1): 5983.

Bowler, Shaun, David M. Farrell, and Richard S. Katz. 1999. "Party cohesion, party discipline, and parliaments." Party discipline and parliamentary government: 3-22.

Carey, John M., and Matthew Soberg Shugart. 1995. "Incentives to cultivate a personal vote: a rank ordering of electoral formulas.” Electoral studies 14(4): 417-439.

Ceron, Andrea. 2012. "Bounded oligarchy: How and when factions constrain leaders in party position-taking." Electoral Studies 31(4): 689-701.

Ceron, Andrea. 2015. "Brave rebels stay home: Assessing the effect of intra-party ideological heterogeneity and party whip on roll-call votes." Party Politics 21(2): 246-258.

Ceron, Andrea. 2014a. "Gamson rule not for all: Patterns of portfolio allocation among Italian party factions.” European Journal of Political Research 53(1): 180-199.

Ceron, Andrea. 2014b. "Inter-factional conflicts and government formation Do party leaders sort out ideological heterogeneity?” Party Politics: 1354068814563974.

Cox, Gary W. 2005. The efficient secret: The cabinet and the development of political parties in Victorian England. Cambridge University Press.

Cox, Gary W., and Mathew D. McCubbins. 2007. Legislative leviathan: Party government in the House. Cambridge University Press.

Cox, Gary W., and Mathew D. McCubbins. 2005. Setting the agenda: Responsible party government in the US House of Representatives. Cambridge University Press.

Debus, Marc, and Thomas Brauninger. 2008. "Intra-Party Factions and Coalition Bargaining in Germany." In Intra-Party Politics and Coalition Governance, 121-145.

Döring, Herbert. 2003. "Party discipline and government imposition of restrictive rules." The Journal of Legislative Studies 9(4): 147-163.

Downs, Anthony. 1957. An economic theory of democracy. New York: Harper. 
Ezrow, Lawrence, Catherine De Vries, Marco Steenbergen, and Erica Edwards. 2011. "Mean voter representation and partisan constituency representation: Do parties respond to the mean voter position or to their supporters?" Party Politics 17(3): 275-301.

Gauja, Anika. 2013. The politics of party policy: From members to legislators. Springer.

Green, Jane. 2011. "A test of core vote theories: The British Conservatives, 1997-2005." British Journal of Political Science 41(4): 735-764.

Green, Jane, and Will Jennings. 2012. "The dynamics of issue competence and vote for parties in and out of power: An analysis of valence in Britain, 1979-1997." European Journal of Political Research 51(4): 469-503.

Greene, Zachary. 2016. "Competing on the issues How experience in government and economic conditions influence the scope of parties' policy messages." Party Politics 22(6): 809-822.

Greene, Zachary David, and Matthias Haber. 2015. "The consequences of appearing divided: An analysis of party evaluations and vote choice.” Electoral Studies 37: 15-27.

Greene, Zachary, and Matthias Haber. 2016. "Leadership Competition and Disagreement at Party National Congresses.” British Journal of Political Science 46(3): 611-632.

Greene, Zachary, and Christian B. Jensen. 2016. "Manifestos, salience and junior ministerial appointments." Party Politics 22: 382-392.

Greene, Zachary, and Diana Z. O’Brien. 2016. "Diverse parties, diverse agendas? Female politicians and the parliamentary party's role in platform formation." European Journal of Political Research 55(3): 435-453.

Haber, Matthias. 2015. "The legislative consequences of internal conflict and inter-party divisions." Research \& Politics 2(2): 2053168015589216.

Harmel, Robert, and Kenneth Janda. 1994. "An integrated theory of party goals and party change." Journal of theoretical politics 6(3): 259-287.

Harmel, Robert, and Alexander Tan. 2003. "Party actors and party change: Does factional dominance matter?” European Journal of Political Research 42(3): 409-424.

Haute, Emilie van, and R. Kenneth Carty. 2012. "Ideological misfits: A distinctive class of party members.” Party Politics 18(6): 885-895.

Haute, Emilie van, and Anika Gauja. 2015. Party Members and Activists. Routledge.

Huber, John D. 1996. "The vote of confidence in parliamentary democracies." American Political Science Review: 269-282.

Ibenskas, Raimondas, and Allan Sikk. 2017. "Patterns of party change in Central and Eastern Europe, 1990-2015.” Party Politics 23(1): 43-54. 
Katz, Richard S., and Peter Mair. 1994. How parties organize: change and adaptation in party organizations in Western democracies. Sage.

Kenig, Ofer. 2009a. "Classifying party leaders' selection methods in parliamentary democracies.” Journal of Elections, Public Opinion and Parties 19(4): 433-447.

Kenig, Ofer. 2009b. "Democratization of party leadership selection: Do wider selectorates produce more competitive contests?" Electoral Studies 28(2): 240-247.

Kitschelt, Herbert. 1989. "The internal politics of parties: the law of curvilinear disparity revisited." Political studies 37(3): 400-421.

Kölln, Ann-Kristin. 2016. "Party membership in Europe Testing party-level explanations of decline." Party politics 22(4): 465-477.

Kölln, Ann-Kristin. 2015. "The effects of membership decline on party organisations in Europe.” European Journal of Political Research: n/a-n/a.

Kölln, Ann-Kristin, and Jonathan Polk. 2017. "Emancipated party members: Examining ideological incongruence within political parties.” Party Politics 23(1): 18-29.

O’Brien, Diana Z. 2015. "Rising to the Top: Gender, Political Performance, and Party Leadership in Parliamentary Democracies." American Journal of Political Science 59(4): 1022-1039.

Poguntke, Thomas et al. 2016. "Party rules, party resources and the politics of parliamentary democracies: How parties organize in the 21st century." Party Politics 22(6): 661678.

Proksch, Sven-Oliver, and Jonathan B. Slapin. 2009. "How to Avoid Pitfalls in Statistical Analysis of Political Texts: The Case of Germany." German Politics 18(3): 323-344.

Schofield, Norman, and Itai Sened. 2006. Multiparty democracy: elections and legislative politics. Cambridge University Press.

Schumacher, Gijs, Catherine E. de Vries, and Barbara Vis. 2013. "Why Do Parties Change Position? Party Organization and Environmental Incentives." The Journal of Politics 75(2): 464-477.

Shomer, Yael. 2016. "The Conditional Effect of Electoral Systems and Intraparty Candidate Selection Processes on Parties' Behavior." Legislative Studies Quarterly.

Shomer, Yael. 2014. "What affects candidate selection processes? A cross-national examination." Party Politics 20(4): 533-546.

Shomer, Yael, Gert-Jan Put, and Einat Gedalya-Lavy. 2016. "Intra-party politics and public opinion: How candidate selection processes affect citizens' satisfaction with democracy." Political Behavior 38(3): 509-534. 
Slapin, Jonathan B., and Sven-Oliver Proksch. 2008. "A Scaling Model for Estimating TimeSeries Party Positions from Texts." American Journal of Political Science 52(3): 705722.

Spoon, Jae-Jae. 2011. Political survival of small parties in Europe. University of Michigan Press.

Spoon, Jae-Jae, and Christopher Williams. 2017. "It takes two: how Eurosceptic public opinion and party divisions influence party positions." West European Politics 40(4): 741-762.

Talbot, Colin. 2015. 'Under the Fixed Term Parliaments Act, a minority Government doesn't need a 'confidence and supply' arrangement to be able to govern." Democratic Audit UK Blog. http://democraticdashboard.com/widget/search-form (Accessed April 1, 2017).

Willumsen, David M., and Klaus H. Goetz. 2017. "Set Free? Impending Retirement and Legislative Behaviour in the UK.” Parliamentary Affairs 70(2): 254-279. 


\section{Appendix}

Table 1: Logistic Regression Models

\begin{tabular}{lcccccc}
\hline & Model & Model 2 & Model 3 & Model 4 & Model 5 & Model 6 \\
\hline Intercept & $-2.86^{*}$ & $-2.82^{*}$ & $-3.10^{*}$ & $-3.34^{*}$ & $-2.84^{* *}$ & $-2.98^{* *}$ \\
& $(1.39)$ & $(1.4)$ & $(1.28)$ & $(1.32)$ & $(0.88)$ & $(0.91)$ \\
Ideological & -0.1 & -0.13 & 0.42 & $0.55^{*}$ & 0.16 & 0.26 \\
Distance & & & & & & \\
& $(0.29)$ & $(0.36)$ & $(0.27)$ & $(0.28)$ & $(0.2)$ & $(0.22)$ \\
In Government & -0.6 & -0.72 & -1.35 & 0.39 & -0.87 & -0.28 \\
& $(0.58)$ & $(0.91)$ & $(0.81)$ & $(1.16)$ & $(0.45)$ & $(0.73)$ \\
Incumbent & $2.78^{*}$ & $2.77^{*}$ & 1.15 & 1.1 & $1.92^{* *}$ & $1.94^{* *}$ \\
& $(1.09)$ & $(1.09)$ & $(0.85)$ & $(0.85)$ & $(0.66)$ & $(0.66)$ \\
Female & -0.21 & -0.21 & 1.08 & 1.16 & 0.38 & 0.4 \\
& $(0.63)$ & $(0.63)$ & $(0.61)$ & $(0.63)$ & $(0.41)$ & $(0.41)$ \\
BME & -13.71 & -13.71 & 0.18 & 0.19 & -0.21 & -0.21 \\
& $(1751.7)$ & $(1750.34)$ & $(1.22)$ & $(1.23)$ & $(1.12)$ & $(1.13)$ \\
Age range & -0.33 & -0.32 & -0.27 & -0.26 & -0.3 & -0.3 \\
& $(0.28)$ & $(0.28)$ & $(0.28)$ & $(0.29)$ & $(0.19)$ & $(0.19)$ \\
Distance $x$ In & & 0.1 & & -1.64 & & -0.49 \\
Gov't & & & & & & $(1.11)$ \\
& 119.79 & 121.76 & 101.15 & 100.54 & 215.98 & 217.03 \\
\hline AIC & 142.81 & 148.07 & 123.88 & 126.52 & 243.71 & 248.72 \\
BIC & -52.90 & -52.88 & -43.57 & -42.27 & -100.99 & -100.51 \\
Log Likelihood & 105.79 & 105.76 & 87.15 & 84.54 & 201.98 & 201.03 \\
Deviance & 198 & 198 & 190 & 190 & 388 & 388 \\
$\mathrm{n}$ & & & & & \\
\hline$* * * \mathrm{p}<0.001,{ }^{* *} \mathrm{p}<0.01,{ }^{*} \mathrm{p}<0.05$ & & & & &
\end{tabular}

Table 2.

\begin{tabular}{lcccccc}
\hline & $(1)$ & $(2)$ & $(3)$ & $(4)$ & $(5)$ & $(6)$ \\
& 2010 & 2010 & 2015 & 2015 & Full & Full \\
\hline Survey & -0.049 & 0.026 & $-0.137^{+}$ & -0.134 & $-0.123^{+}$ & -0.096 \\
Distance & & & & & & \\
& $(0.109)$ & $(0.100)$ & $(0.070)$ & $(0.077)$ & $(0.072)$ & $(0.089)$ \\
Government & $-0.406^{* *}$ & -0.128 & -0.115 & -0.077 & $-0.268^{*}$ & -0.098 \\
& $(0.126)$ & $(0.209)$ & $(0.200)$ & $(0.119)$ & $(0.105)$ & $(0.112)$ \\
Government & & -0.298 & & -0.050 & & -0.188 \\
X Survey & & & & & & \\
Distance & & & & & & $(0.237)$ \\
Constant & $0.785^{* * *}$ & $(0.190)$ & & & & $0.119)$ \\
& $(0.099)$ & $\left(0.140^{* * *}\right.$ & $0.747^{* * *}$ & $0.744^{* * *}$ & $0.785^{* * *}$ & $0.764^{* * *}$ \\
\hline RMSE & 0.249 & 0.245 & $(0.115)$ & $(0.119)$ & $(0.070)$ & $(0.075)$ \\
$N$ & 21 & 21 & 0.421 & 0.437 & 0.328 & 0.330 \\
\hline
\end{tabular}


Figure 1: Change in predicted probabilities by ideological distance, 2015.

Change in Probabilities

MiniMax variation of Ideological Distance

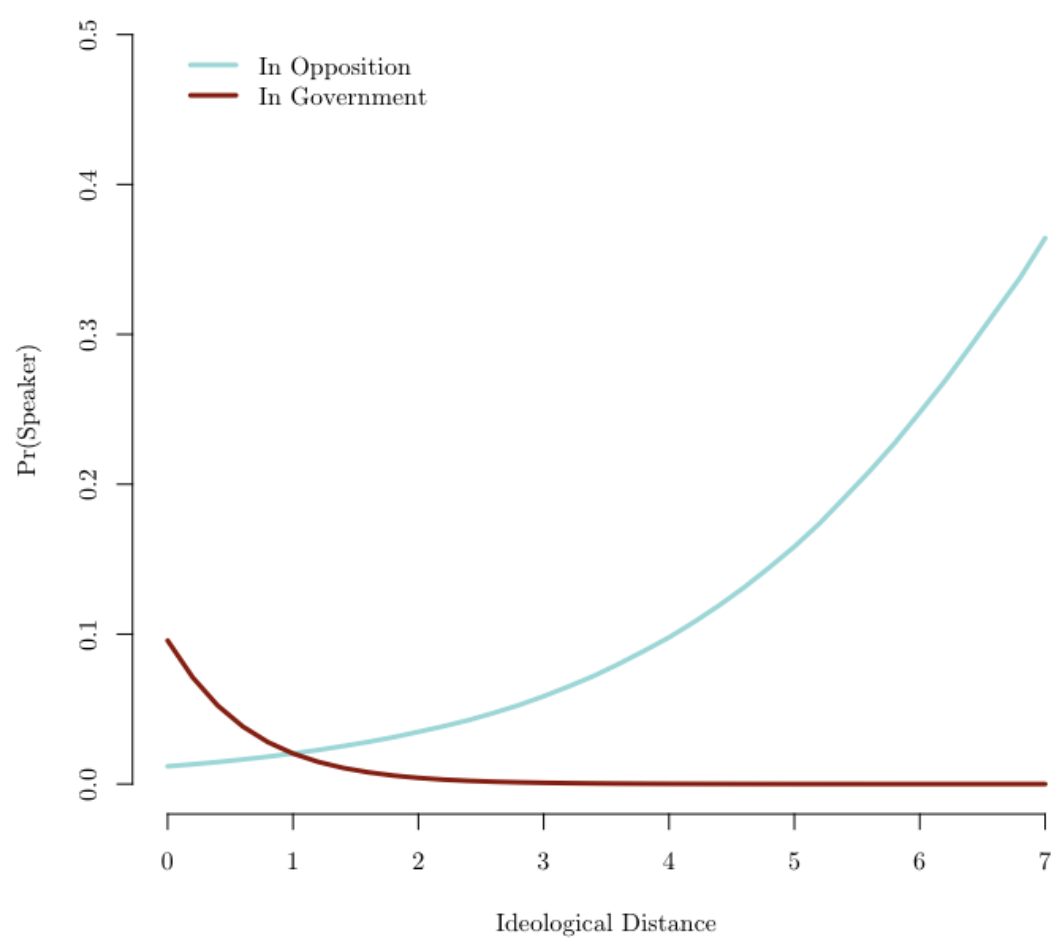

Figure 2. Word weights for 2010

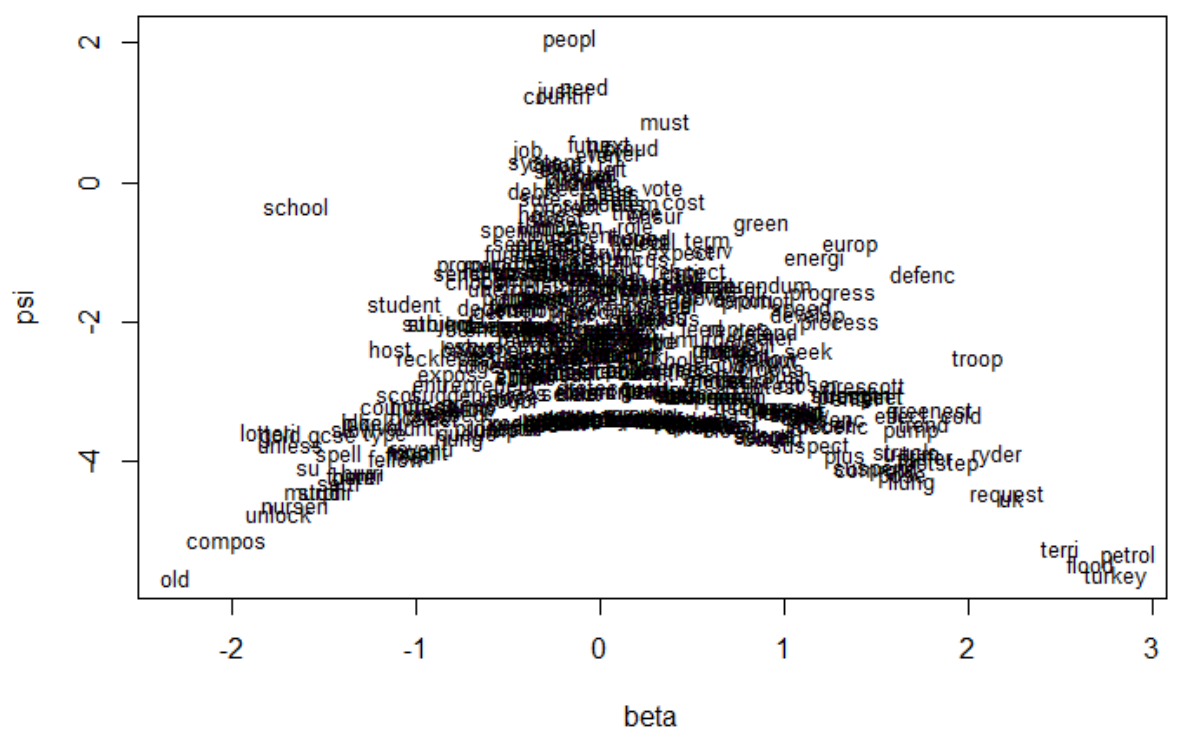

Figure 3. Word weights for 2015 


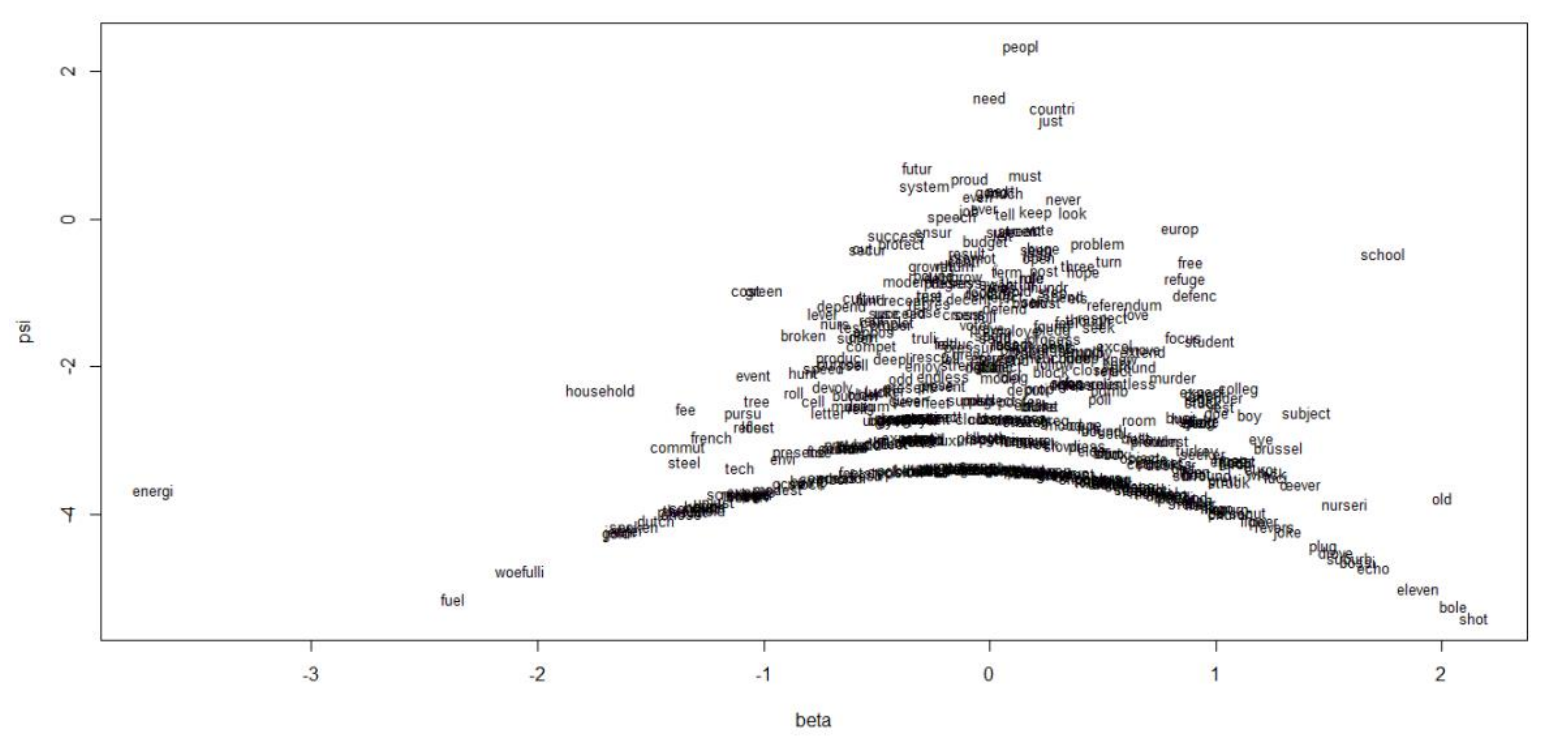

Figure 4. Correlation between Wordfish scores and CCS self-declared scores in 2015

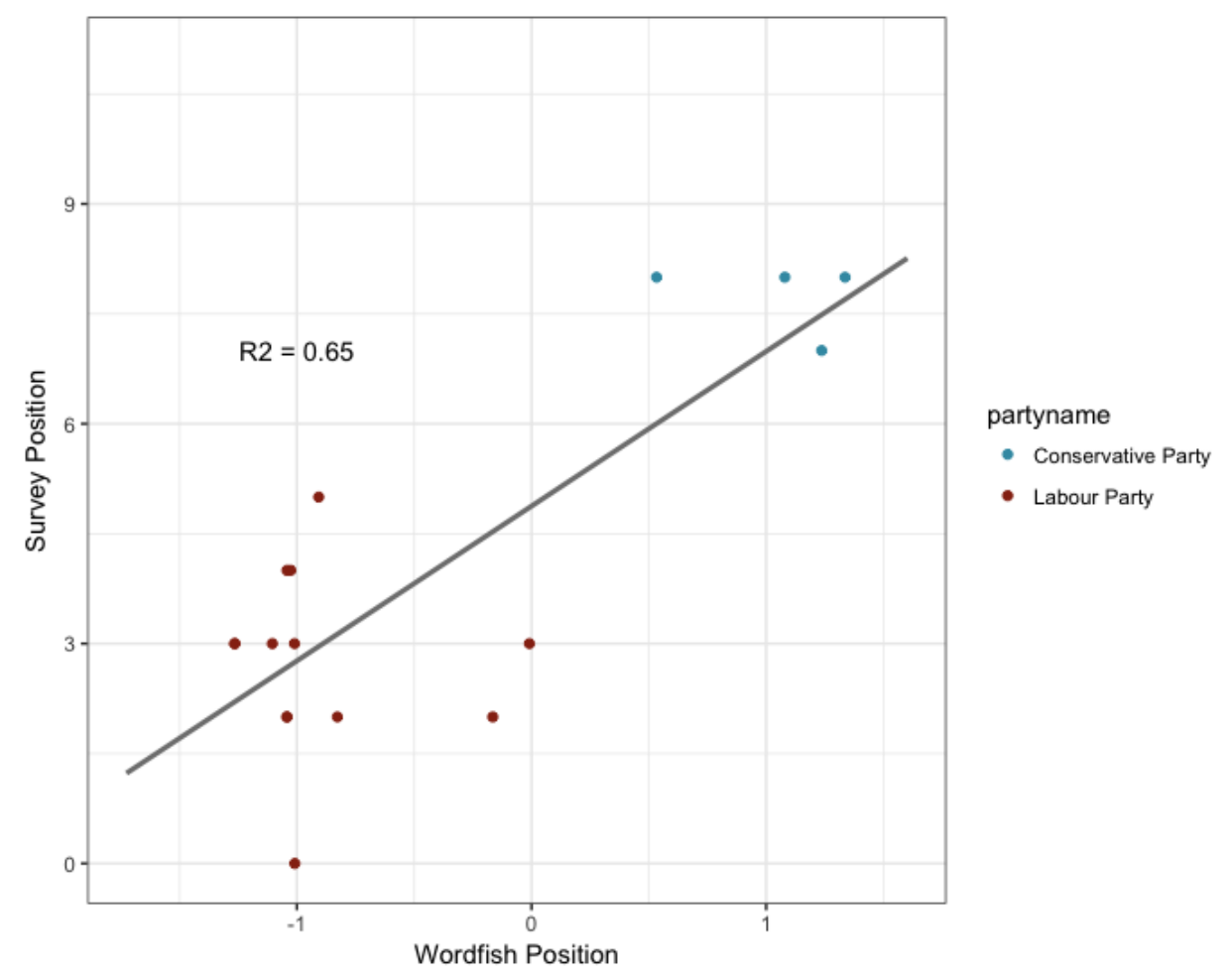

